\title{
Stachybotrys chartarum as A Bio-Agent to Control Orobanche spp
}

\author{
O.A.AL-MenoufI
}

\begin{abstract}
The fungus Stachybotrys chartarum was isolated from Orobanche seeds, which were collected from different localities of the Nile Delta, Egypt. In pot trials, mycelial suspension, as well as, the fungal filtrate completely prevent the attack of O.crenata to faba bean (Vicia faba) with. Also, fungal filtrate completely inhibited the germination of O.crenata and O.ramosa seeds induced by the synthetic germination stimulant $\mathbf{G R}_{\mathbf{2 4}}$. Such effect was attributed to the presence of mycotoxin(s) secreted by the fungus.
\end{abstract}

\section{INTRODUCTION}

Control of broomrape (Orobanche spp.) is considered a rather difficult problem because of the tremendous amount of produced minute seeds, their long life span and its requirement of a special stimulant released from roots of particular plants to break seed dormancy.

Biological control by using secondary parasites, fungi or insects, was suggested as a successful control procedure. In this respect, Alternaria spp. Fusarium culmorum, $F$. gibbsum, $F$. lateritium, $F$. moniliform, $F$. orobanchia, $F$. oxysporum, $F$ solani., $F$. sambucinum, $F$. semitectum, Rhizoctonia solani, Sclerotinia sp and Verticillium microsporum gave good indications as potential biological agents to Orobanche spp. (Dufala et al., 1976; Al-Menoufi, 1986; Turhan, 1990; Bedi and Donchev, 1991; Bedi, 1994; Souerborn et al., 1994 and Komeil, 2005).

Stachybotrys spp. are saprophytic imperfect fungi isolated from wheat and rice grains and straw, dust, air, and many other biotic and abiotic organic and inorganic materials (Abdel-Hafez and Shoreit, 1985; Khallil, 1990 and Udaiyan, 1992). Some mycotoxins such as zearalenone and zearalenol were isolated and identified as metabolic byproducts of these fungi causing stachybotritoxicosis and other disorders for man and some animals (Servatie et al.,1985 and El-Kady et al.,1989 and El-Maghraby et al., 1991). S. bisbyi was isolated from sugarcane causing the red leaf spot disease (Singh et al., 1987). On the other hand, S. atra is considered as a biocontrol agent for some viral and fungal diseases (Siqueira et al., 1984; Maiss, 1987; Kapoor and kar, 1988 and Ehteshamul-Haque and Ghaffar, 1991).
The present work was designed to investigate the effect of $S$. chartarum (Ehrenb.) Hughes which was isolated from $O$. crenata Forsk seeds, on the germination of $O$. crenata and $O$. ramosa $L$., as well as on the ability of $O$. crenata to parasitize faba bean (Vicia faba) plants.

\section{MATERIALS AND METHODS}

A fungus associated with ungerminated $O$. crenata seeds (in the synthetic germination stimulant $\mathrm{GR}_{24}$ medium) was isolated, purified on potato dextrose agar (PDA) medium and identified by Centraalbureau Voor Schimmelcultures, Braan, the Netherlands.

Fungal mycelial mats and filtrates were prepared by inoculating $250 \mathrm{ml}$ conical flasks containing $100 \mathrm{ml}$ of potato dextrose liquid medium with disks $(0.5 \mathrm{~cm}$ diameter) from 21-days old fungal cultures growing on PDA at $20^{\circ} \mathrm{C}$. Flasks were incubated for $21-25$ days at $20^{\circ} \mathrm{C}$. Mycelial suspension was prepared by blending the harvested mycelial mats in distilled water $(1 \mathrm{mat} / 100 \mathrm{ml})$ to be used in pot experiments. Fungal filtrate was sterilized by Zeitz filter to be used in the germination and pot experiments. The effect of filtrates heated at $60^{\circ} \mathrm{C}$ for 30 mins. or autoclaved $\left(121^{\circ} \mathrm{C}\right.$ for 15 mins.) on the germination of $O$.crenata and $O$. ramose seeds, as well as, their effect on the number of $O$. crenata plants attached to faba bean roots were also investigated

To study the effect of fungal filtrate on seed germination of $O$. ramosa and $O$. crenata, preconditioned seeds were placed onto filter papers in Petri dishes containing $3 \mathrm{ml}$ of the synthetic germination stimulant $\mathrm{GR}_{24}$ alone or mixed with fungal filtrate $(1: 1$, v:v). Petri dishes were then incubated for 4-5 days at $20^{\circ} \mathrm{C}$ before counting the germinated seeds. Treatments were replicated six times in a complete randomized block design.

Pots (25-cm diameter) with 30 days old faba bean plants (4 plants/pot) were treated with the mycelial suspension or filtrates $(100 \mathrm{ml} / \mathrm{pot})$. Pots were previously infested with $O$. crenata seeds $(0.025 \mathrm{~g} / \mathrm{pot}=2500$ seeds). Pots uninfested with $O$. crenata seeds, were also treated with mycelial suspension or filtrate. Untreated pots, infested or uninfested with $O$. crenata seeds, were served as control treatment. Treatments were replicated ten times in a complete randomized block design. Number of Orobanche attachments on faba bean plants was counted 90 days after sowing.

${ }^{1}$ Faculty of Agriculture, Alexandria University, Egypt.

Received Novaber 23, 2010, Accepted Desamber 22, 2010. 


\section{RESULTS AND DISCUSSION}

Data (Table1) revealed that $O$. ramosa and $O$. crenata seeds are readily germinated with 1 PPM GR 24 (83.4 \% and $71.0 \%$, respectively). By adding the $S$. chartarum filtrate to the $\mathrm{GR}_{24} 2$ PPM solution $(1: 1, \mathrm{v}: \mathrm{v})$, the germination of Orobanche seeds was completely inhibited $(0.0 \%)$. Slight germination was detected when fungal filtrate was previously heated $(5.3 \%$ and $2.8 \%$ for $O$. ramosa and $O$. crenata, respectively) or autoclaved $(6.7 \%$ and $3.1 \%$ for $O$. ramosa and $O$. crenata, respectively). Statistical analyses revealed that reduction in germination due to the fungal filtrates is highly significant.

In pots treated with either mycelial suspension of $S$. chartarum or its filtrate, the growing faba bean plants were completely free from broomrape attachments. Faba bean plants in untreated pots were parasitized by 4-9 broomrape plants with an average of 5.7 parasite/host plant. Either the mycelial suspension or the fungal filtrate did not affect the growth of faba bean plants.

The obtained results revealed that the $S$. chartarum secrets a thermostable mycotoxin(s), which might inhibit the germination of Orobanche, seeds or block the stimulatory effect of $\mathrm{GR}_{24}$. It is known that Stachybotrys spp produce certain mycotoxins such as zearalenone and zearalenole(El-Kady et al.,1989). The inhibitory effect of $S$. chartarum on Orobanche seed germination might be due to these mycotoxins.

According to the above mentioned results it concluded that the fungus $S$. chartarum might be a promising biocontrol agent for Orobanche. Further investigations are needed to verify such results and to avoid any harmful effect(s) on other living organisms.

Table 1. Effect of Stachybotrys chartarum filtrate (FF) on the germination of Orobanche seeds treated with the synthetic germination stimulant $\mathbf{G R}_{\mathbf{2 4}}$

\begin{tabular}{lcc}
\hline \multirow{2}{*}{ Treatment } & \multicolumn{2}{c}{ Germination Percentage } \\
\cline { 2 - 3 } & O. ramosa & O. crenata \\
\hline $\mathrm{GR}_{24} \quad 1 \mathrm{ppm}$ & 83.4 & 71.0 \\
\hline $\mathrm{FF}$ & 0.0 & 0.0 \\
\hline $\mathrm{FF}+\mathrm{GR}_{24}{ }^{1}$ & $0.0^{* *}$ & $0.0^{* *}$ \\
\hline Heated $\mathrm{FF}+\mathrm{GR}_{24}{ }^{1}$ & $5.3^{* *}$ & $2.8^{* *}$ \\
\hline Autoclaved $\mathrm{FF}+\mathrm{GR}_{24}{ }^{1}$ & $3.1^{* *}$ & $6.7^{* *}$ \\
\hline L.S.D. $\mathbf{0 . 0 1}$ & 9.3 & 8.5 \\
\hline
\end{tabular}

${ }^{\mathrm{T}} \mathrm{FF}+\mathrm{GR}_{24}(2 \mathrm{ppm})$ at the rate of $1: 1(\mathrm{~V}: \mathrm{V})$

\section{REFERENCES}

Abdel-Hafez, S.I.I. and Shoreit, A.A.M. (1985).Mycotoxins producing fungi and mycoflora of air dust from Taif-Saudi Arabia. Mycopathologia 92 (2): 65-71.

Al-Menoufi, O.A. (1986). Studies on Orobanche spp. 2: Fungi associated with Orobanche crenata Forsk. Alexandria Journal of Agriculture Research 31: 311-322.
Bedi, J.S. and Donchev, N. (1991). Results in mycoherbicide control of sunflower broomrape (Orobanche cernua Wall.) under glasshouse and field conditions. pp. 76-79. in Ransom, J.K., Musselman L.J., Worsham A.D. and Parker, C. (eds.) Proceedings of the 5th International Symposium of Parasitic Weeds. Nairobi, CIMMYT.

Bedi, J.S. (1994). Further studies on Fusarium oxysporum f.sp. orthcerase, a potential mycoherbicide. In: Pieterse, A.H.; Verkleij, J.A.C. and ter Borg, S.J. (eds.), Biology and Management of Orobanche, Proceedings of the Third International Workshop on Orobanche and Related Striga Research. Amsterdam, The Netherlands, Royal Tropical Institute. pp: 539-544.

Dufala, T.; Wilhelm, S.; Gold, A.H. and Sagen, J.E. (1976). Rhizoctonia disease of broomrape, a possible biological control. In proceedings, The American Phytopathological Society, $3: 272$.

Ehteshamul-Haque, S. and Ghaffar, A. (1991). Biological control of root rot of mustard. Pakistan Journal of Botany 23 (2): 194- 198.

El-Kady, I.A.; Moubasher, A.H. and El-Maraghy, S.S.M. (1989). Zearalonen production by several genera of fungi other than Fusarium. Egyptian Journal of Botany 31( 1-3): 99-108.

El-Maghraby, O.M.O.; Bean, G.A.; Jarvis, B.B. and Aboulnasr, M.B. (1991). Macrocyclic trichothecenes produced by Stachybotrys sp isolated from Egypt and Eastern Europe. Mycopathologia 113 (2) :109-115.

Kapoor, I.J. and kar, B. (1988). Antagonestic effects of soil microbes on Fusarium oxysporum f.sp. lycopercisi, causing tomato wilt. International Journal of Tropical Plant Diseases 6 (2): 257-262.

Khallil, A.R.M.A. (1990). Mycoflora associated with some freshwater plants collected from Delta region (Egypt). Journal of Basic Microbiology 30 (9): 663-674.

Komeil, Doa'a A. (2005). Studies on Parasitic Flowering Plants in Egypt. M.Sc. Thesis, Plant Pathology Dept., Faculty of Agriculture, Alexandria University.

Maiss, E. (1987).Use of resistance induction through culture filtrates of Stachybotrys charatum (Ehrenb. ex Link) Hughes and Bacillus subtilis (Ehrengerg) Cohn against virus diseases under commercial conditions of crop production. Archiv fuer Phytopathologie und Pflazenschutz (German D.R.) 13 (4): 275-283.

Sauerborn, J.A; Abbasher, A. and Kroschel, J. (1994). Biological control of parasitic weeds by phytopathogenic fungi. In: Pieterse, A.H.; Verkleij, J.A.C.and ter Borg, S.J. (eds.), Biology and Management of Orobanche, Proceedings of the Third International Workshop on Orobanche and Related Striga Research. Amsterdam, The Netherlands, Royal Tropical Institute. pp: 539-544.

Servantie,J.; Le Bars,J. and Bonnfoi,M. (1985). Equine stachybotryotoxicosis: first description in France [Stachybotrys atra, myopathy]. Revue de Medecine Veterinaire 136 (10): 687-692. 
Singh, G.P.; Gupta, S.C.; Mirsa, S.C. and Solanki, R.S. (1987). Recent studies on red leaf spot of sugarcane in Uttar Pradesh. Pestcides 21 (9): 19-20.

Siqueira, J.O.; Hubbell, D.H.; Kimbrough, J.W. and Schenck, N.C. (1984). Stachybotrys charatum antagonestic to azygospores of Gigspora margrita in vitro. Soil and Biochemistry 16 (6): 679-681.
Turhan, G. (1990). Further hypoparastism of Rhizoctonia solni Kuhen as promising candidates for biological control. Zeitschrift fuer Pflanzenkrankeiten und Pflanzenschutz. 97 (2): 208-215.

Udaiyan, K. (1992). Some interesting hyphomycetes from the industrial water cooling towers of Madras. Journal of Economic and taxnomic Botany 15 (3): 627-647. 


\section{الملخص العربي}

\section{إستاكيبوتريس كارتارم مبيد حيوى للهالوك}

$$
\text { اسامة عبد الحميد المنوفى }
$$

بينـت النتائج أن إفرازات الفطر الطبيعية والمخففـة بالماء (1:1) تمنع تمام إنبات بذور الهالوك بنوعيه.

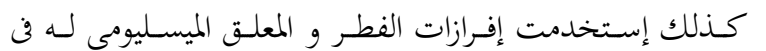

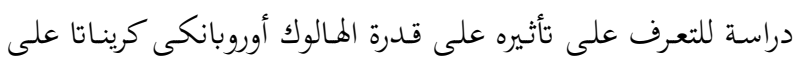

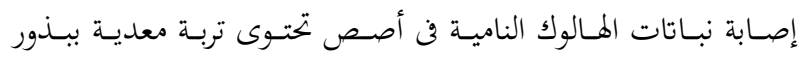

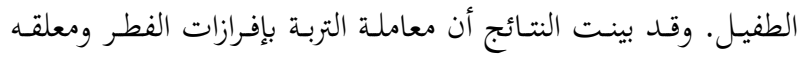
الميسيليومى منعت تماما إصابة الفول بالهالوك.
تم عزل الفطر إستاكيبوتريس كارتارم من بذور هالوك سبق بتميعها

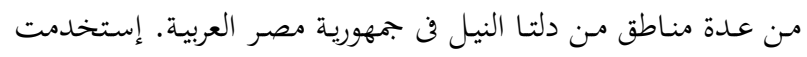

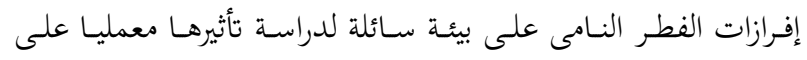

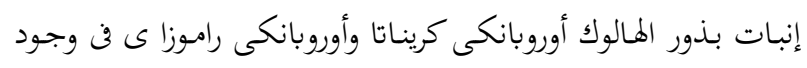
مادة GR المخلقة لتنبيه إنبات بذور الهالوك. 